\title{
An electrochemical analysis of acute contamination of environmental water and restoring of water quality using taro carbon
}

\author{
Efdtekhar U. M. Aman ${ }^{1} \cdot$ Md. Fahamidul Islam ${ }^{1}$ (1) $\cdot$ Tahmid A. Chowdhury $^{2} \cdot$ Md. Saiful Alam $^{1} \cdot$ Md. Elias $^{3}$. \\ Md. Nizam Uddin ${ }^{1} \cdot$ Ahmed J. Samed ${ }^{1} \cdot$ Mohammad A. Hasnat $^{1}$ (I)
}

Received: 9 December 2019 / Accepted: 6 May 2020 / Published online: 26 May 2020

(c) The Author(s) 2020

\begin{abstract}
Electrochemical techniques were successfully employed to estimate contamination of water of river Buriganga, Bangladesh. A Pt-Cu electrode has been exploited to measure selective nitrate concentration, and corrosion rate of iron has been proposed to indicate relative abundance of dissolved contaminants. In order to evaluate the pollution level, water parameters of river Buriganga have been compared with those obtained from two freshwater streams named Surma and Dawki of the country. An iron strip in contact with Buriganga river water is corroded three times rapidly compared to its contact with Dawki or Surma river water indicates acute contamination of Buriganga river water. The River Buriganga is facing acute pollution from the point of high TDS (0.664-0.694 g/L), low DO (1.47-4.4 mg/L), high COD (197-218 mg/L), high ammonia (270-420 mg/L) and high nitrate concentration $(107-157 \mathrm{mg} / \mathrm{L})$. Negative ORP value $(-292$ to $-310 \mathrm{mV})$ of Buriganga river water indicates that the stream contains high level reducing species. Meanwhile, positive ORP value indicates that Dawki $(+203$ to $+209 \mathrm{mV}$ ) and Surma (+184 to $+205 \mathrm{mV}$ ) river water contain oxidizing species. Sediment analysis shows the deposition of disintegrated organic pollutants on the bottom of the River Buriganga. Cost-effective carbon material synthesized from taro stems has been proposed to restore water parameters of filthy water system like Buriganga river.
\end{abstract}

Keywords Nitrate $\cdot$ Ammonia $\cdot$ TDS $\cdot$ DO $\cdot$ Sediment $\cdot$ Taro carbon

\section{Introduction}

Owing to various reasons water quality, especially surface water of our beloved planet is being polluted repeatedly. The reasons include natural processes (e.g., heavy rain, flood, precipitation, soil erosion, reduction of flow, etc.), anthropogenic activities (e.g., deforestation, urbanization, industrialization, inadvertent agricultural practices, etc.) and the immense applications of water resources (Dwivedi et al. 2018). The increasing pollution by various contaminants

Mohammad A. Hasnat

mah-che@sust.edu; mahtazim@yahoo.com

1 Department of Chemistry, School of Physical Sciences, Shahjalal University of Science and Technology,

Sylhet 3100, Bangladesh

2 Department of Geography and Environmental Sciences, School of Physical Sciences, Shahjalal University of Science and Technology, Sylhet 3100, Bangladesh

3 Department of Chemistry, Jagannath University, Dhaka, Bangladesh has a significant adverse health effects for marine lives and humans (Wang and Yang 2016; Kubicz et al. 2018; Falkenberg et al. 2018). Due to increased pollution, fresh water has now become important commodity worldwide. According to latest report, approximately 2.1 billion people over the world do not have admittance to adequate sources of drinking water (WHO 2017). Note that the Buriganga is one of the important rivers in Bangladesh. The city of Dhaka is known as one of the most densely populated (density over 40,000/ $\mathrm{km}^{2}$ ) cities over the glove (Kabir et al. 2018). Because of rapid and unplanned urbanization, the dwellers of this city are experiencing lack of planned waste disposal maintenance. Consequently, once mighty river Buriganga is now become filthy water stream in this country because of rampant dumping of human and industrial waste (Kamal et al. 1999). There are so many chemicals that may contaminate a water system. The total dissolved solids (TDS) vary typically in lakes and streams within the range of $50-250 \mathrm{mg} / \mathrm{L}$. In the areas of hard water or high salinity or sea water intrusion, TDS values may be as high as $500 \mathrm{mg} / \mathrm{L}$. According to United States Environmental Protection Agency, 
acceptable level of TDS in drinking should be $500 \mathrm{mg} / \mathrm{L}$ or less than $500 \mathrm{mg} / \mathrm{L}$. While organic wastes are dumped, they are decomposed by bacterial activities. In marine waters, nitrogenous compounds are converted into ammonia by consuming dissolved oxygen (DO) and then ammonia is converted into nitrites and nitrates. According to world health organization (WHO), normal level of ammonia in ground waters exist below $0.2 \mathrm{mg} / \mathrm{L}$, whereas surface waters may contain as high as $12 \mathrm{mg} / \mathrm{L}$ (WHO 2003). Meanwhile, tolerable threshold of nitrate ion concentration in groundwater is $50 \mathrm{mg} / \mathrm{L}$ (Wick et al. 2012). Electrochemical sensors are one of the green techniques and thereby playing a vital role to detect and quantify environmental hazards from water (Khan and Khan 2010; Khan et al. 2013, 2016; Rahman et al. 2015; Deng and Li 2018; Farzbod and Moon 2018). These sensors are extremely popular because of their remarkable experimental simplicity, sensitivity, and low cost. The chemical sensors have drawn the top attention among the currently available sensors satisfying the curtail requirements to be used in the commercial stage. Concurrently, these sensors have shown efficiency in a wide range of important applications such as in the fields of industrial, environmental, clinical, and agricultural analyses (Moya et al. 2017; Su et al. 2018). As a result, electrochemical sensors are accounted for approximately $58 \%$ of all chemical sensors. Several sensors and methods have been reported in the literature based on the application and selectivity. For example, a copper-based electrode can be applied for measuring nitrates from water (Alam et al. 2015). Electrochemical impedance spectra can be used for quantifying solution conductivity and charge carriers (Tanjila et al. 2016). Meanwhile, by measuring open circuit potential (OCP) and evaluating corrosion current of a metal, it may be possible to speculate the types of species present in an aquatic system (Sander et al. 1996; McCafferty 2005; Jegdić et al. 2008). Here, we have proposed iron corrosion rate as an indicator of water quality. However, in the past years, the river Buriganga supplied major fraction of water for the dwellers of Dhaka city for domestic, industrial, and irrigational purposes. Because of acute contamination, nowadays, water of this river is not useable. After Kamal et al., no significant studies have been documented pertaining to determination of contaminants in the Buriganga river (Kamal et al. 1999). In order to treat wastewater like Buriganga, several processes such as chemical, Fenton oxidation, chemical coagulation, electro-coagulation, biological degradation(aerobic and anaerobic), adsorption and membrane separation process (Rezakazemi et al. 2018; Sheikh et al. 2019; Mirqasemi et al. 2020; Tavangar et al. 2020) are available but unfortunately no report has yet been published which recommends how the water parameters of Buriganga river water may be restored. Thus, the aim of this study is to report contamination level of Buriganga river and propose a cost-effective method so that water parameters can be restored.

In the present work, we have employed different electrodes to detect and quantify the pollutants in terms of dissolved solid, dissolved oxygen, nitrate contamination, ammonia, etc. Later the results were cross-checked with the data obtained using commercial membrane-based electrodes. In order to understand the level of pollution of Buriganga river, the obtained data have been compared with respect to data received for fresh water samples collected from the rivers Surma and Dawki which are located in the north-east region of Bangladesh down to the topmost rainy region (The Meghalaya State, India) on the glove (World Atlas; Soja and Starkel 2007). It is well known that carbon materials are often used to treat wastewater which can be synthesized from different plants. In the present case, we selected taro stem (Colocasia esculenta), which is extensively available everywhere over the planet, as a potential carbon source. In this article, we have shown how the water parameters of Buriganga river water could be improved followed by treating with taro carbon.

\section{Experimental}

\section{Study area}

The river Buriganga is situated at the southern part Dhaka City, the capital of Bangladesh. Geographically, it is located altitude between $23^{\circ} 36^{\prime} \mathrm{E}$ and $23^{\circ} 46^{\prime} \mathrm{E}$, with longitude between $90^{\circ} 14^{\prime} \mathrm{N}$ and $90^{\circ} 36^{\prime} \mathrm{N}$ (see Fig. 1). This river is originated as a result of confluence of the river Padma (Ganges) and the river Dhaleswari, which, is a distributary, $160 \mathrm{~km}$ long of the Jamuna River in central Bangladesh. The Lakhya River is combined to the Dhaleswari, approximately $11 \mathrm{~km}$ downstream of the Buriganga confluence, which is then merged into the Meghna River, just upstream of the Padma confluence near Chandpur. The Buriganga takes stream mainly from the river Turag, which receives spill flows from the river Jamuna and local rain fall. The lower reaches of the Buriganga-Dhaleswari-Lakhya river system are tidal during the dry season (November-March) when upstream inflows are nominal (Kamal et al. 1999). The average width and depth of the river Buriganga are $400 \mathrm{~m}$ and $10 \mathrm{~m}$, respectively. This river is only $27 \mathrm{~km}$ long. The sampling was performed from 10 major points of the river. The samples were also collected from two rivers named Surma and Dawki. Both of these rivers are located in the northeastern region of Bangladesh which carry flows due to rain fall in the Meghalaya, India, which is known as the most rainy region over the glove where the annual rainfall is even up to $23,000 \mathrm{~mm}$ (Soja and Starkel 2007). Therefore, the 


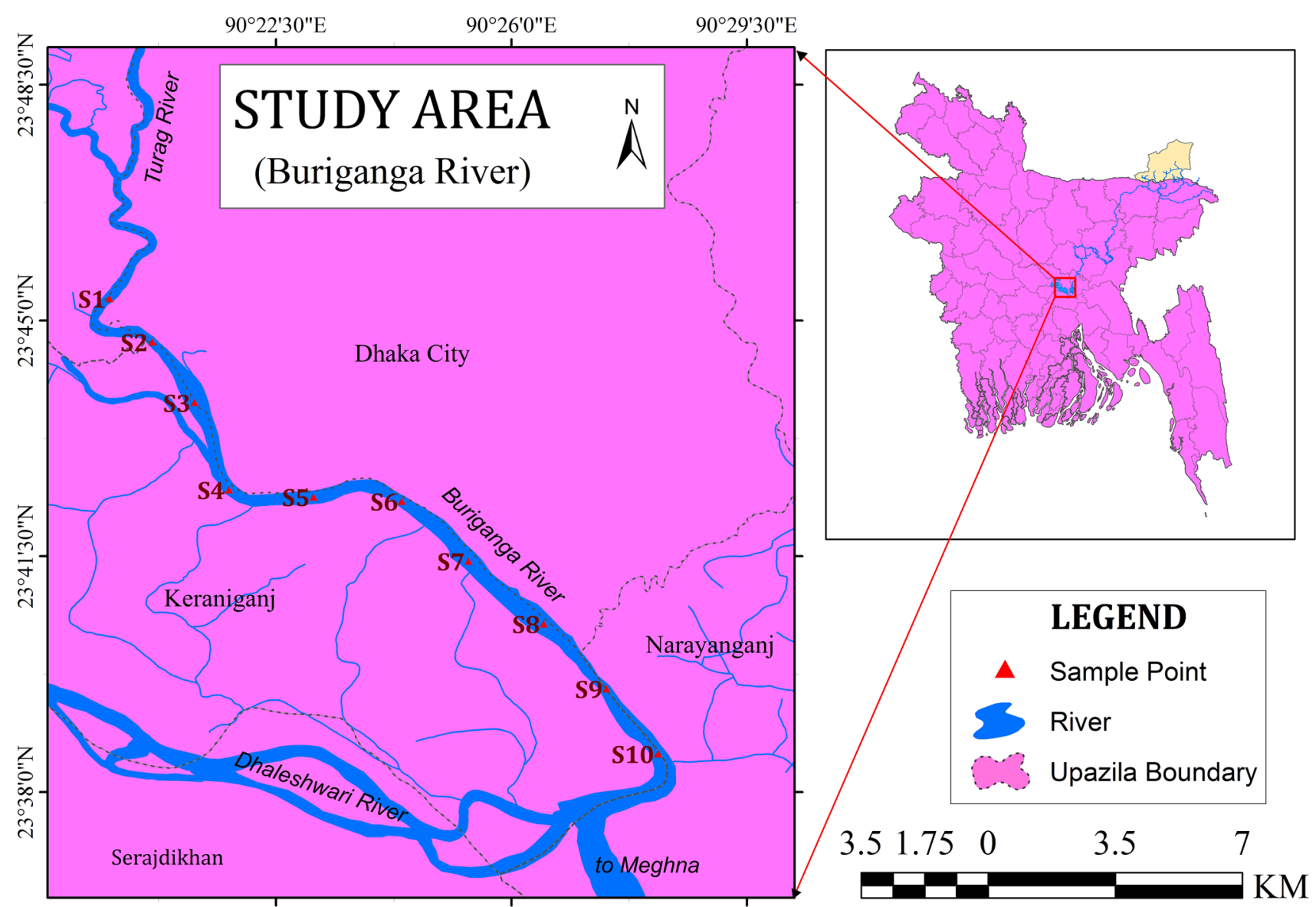

Fig. 1 The study area: River Buriganga, Dhaka, Bangladesh

waters of these rivers are fresh and clean, which are ideal for any reference of study in terms of purity.

\section{Electrochemical investigations}

The electrochemical investigations such as cyclic voltammetric (CV), open circuit potential (OCP) and electrochemical impedance spectroscopic (EIS) measurements were carried out using an Autolab potentiostat (PGSTST $128 \mathrm{~N}$, The Netherlands) in a conventional three-electrode cell. A Teflon-coated Pt electrode ( $2 \mathrm{~mm}$ in diameter) functioned as a working electrode, where an $\mathrm{Ag} / \mathrm{AgCl}$ (sat. $\mathrm{KCl}$ ) and a $\mathrm{Pt}$ wire acted as reference and counter electrodes, respectively. Before the experiments, a bare Pt electrode was mechanically polished with alumina $(0.3 \mu \mathrm{m})$ slurry on a soft lapping pad until a mirror-like shiny surface was attained. A Pt electrode was employed to predict the presence of relative abundance of dissolved oxygen. Meanwhile, a Pt-Cu electrode was employed to infer the presence of reducible substances in the river waters. In order to prepare a $\mathrm{Pt}-\mathrm{Cu}$ electrode, a Pt disk electrode ( $2 \mathrm{~mm}$ diameter) was cycled between 0 and $-0.8 \mathrm{~V}$ in $0.01 \mathrm{M} \mathrm{CuSO}_{4}$ solution for five times at scan rate of $100 \mathrm{mV} / \mathrm{s}$. This approach yielded a thin over layer of $\mathrm{Cu}$ metal particles on $\mathrm{Pt}$ surface. Then, the $\mathrm{Pt}-\mathrm{Cu}$ electrode was washed with distilled water and dried at $60{ }^{\circ} \mathrm{C}$ for several minutes before use. All the electrochemical measurements were performed under aerated condition. The open circuit potential and Tafel slope was evaluated by using a cylindrical ( $r: 2 \mathrm{~mm}$ and $h: 3 \mathrm{~mm})$ iron electrode.

\section{In situ determination of $\mathrm{pH}, \mathrm{TDS}, \mathrm{ORP}, \mathrm{DO}$, Nitrate and ammonia}

Temperature, $\mathrm{pH}$, TDS and ORP were measured on site using LAQUAact PD110 m (Horiba, Japan). The $\mathrm{NO}_{3}{ }^{-}$detection was performed using Horiba LAQUAtwin Nitrate $\mathrm{NO}_{3}^{-}$Meter $\left(\mathrm{NO}_{3}{ }^{-} 11\right)$. For this purpose, the research group collected samples from 10 different locations within $27 \mathrm{~km}$ length of the river Buriganga from where 17 different samples were collected for analysis. In order to obtain data, the sensor was immerged $50 \mathrm{~cm}$ depth down to the surface of the water level. In situ ammonia was measured colorimetrically using an ammonia meter (Mi405 Photometer) supplied by Milwaukee (Hungary). In this case, Nessler 
reagent was added to the $5 \mathrm{~mL}$ samples containing ammonia, which made the samples to turn into a yellowish hue. The associated color change was then colorimetrically analyzed by exploiting the principle of Beer-Lambert Law. According to this law, light is absorbed under an ambient environment and the complimentary color intensity of the emitted radiation determines the concentration. In the presence of $\mathrm{N}\left(-\mathrm{NH}_{3}\right)$, a narrow band interference filter at $420 \mathrm{~nm}$ allows only the violet light to be detected by the silicon photodetector and omits all other visible light emitted from the tungsten lamp. The emitted light intensity is automatically converted into ammonia concentration. Additionally, chemical oxygen demand (COD) was also checked. All the analytical measurements were performed three times. The detailed experimental procedure is described in elsewhere in the literature (Maria Rahman et al. 2014).

\section{Sediment analysis}

Sediments were collected from different locations of the rivers (approximately 1-2 $\mathrm{m}$ deep from the level of water). Next, the as-collected samples were dried at $110^{\circ} \mathrm{C}$ and meshed properly. Then, the materials were evaluated by FESEM instrument (FESEM; JSM-7600F, Japan). At the same time, energy dispersive $\mathrm{X}$-ray analysis (EDS) was performed by using FESEM-coupled XEDS from JEOL, Japan.

\section{Recovery of water parameters}

The restoration studies of water parameters of Buriganga river water was performed using carbonous adsorbent derived from the taro stems. For this purpose, taro stem collected from local area were cut into $3 \mathrm{~cm} \times 2 \mathrm{~cm}$ sizes and then dried at open air at $40{ }^{\circ} \mathrm{C}$ for several hours to remove water content. Next, the dried material was pulverized using a commercial blender and screened using 80-micron sieves. In a 500-mL beaker, $25 \mathrm{~g}$ of sieved material was taken along with $50 \mathrm{~mL}$ of concentrated $\mathrm{HCl}$. This mixture was then sonicated for 90 min such that a dispersion carbon material is prepared, followed by addition of $200 \mathrm{ml}$ DI water. The mixture was then blended for an hour and kept rest for another $1 \mathrm{~h}$ such that a distinct layer of solid phase and aqueous phase are seen. The carbon materials were collected carefully by filtration method and washed repeatedly. After drying at $110^{\circ} \mathrm{C}$, the resulting mass was then transferred to alumina crucible and placed in $\mathrm{N}_{2}$ saturated furnace. Finally, the crucible was heated to $500{ }^{\circ} \mathrm{C}$ gradually and kept at this temperature for $6 \mathrm{~h}$, which yielded black colored mass. In this way, activated carbon was prepared from taro stem. Batch experiments were performed using this taro carbon where the volume of wastewater was $500 \mathrm{~mL}$ in each case with variable amounts of taro carbon. The detailed experimental procedure is given in Scheme 1.

\section{Results and discussion}

\section{Relative conductivity and oxygen abundance}

Figure 2 shows the EIS spectra recorded using a Pt disk electrode at $0 \mathrm{~V}$. An EIS spectrum is typically presented in the form of a complex plane plot, where $Z^{\prime}$ and $Z^{\prime \prime}$ represent the imaginary parts of impedance, respectively. For a classical non-polarizable system, the circuit comprises a series junction of solution resistance $\left(R_{\mathrm{s}}\right)$ along with a parallel combination of a double-layer capacitance $\left(C_{\mathrm{dl}}\right)$ and charge transfer resistance $\left(R_{\mathrm{ct}}\right)$. Note that irrespective of river water, semicircles appeared in each case with different radius indicating some charge transfer process occurring at the electrode-river water systems. At the higher frequency region of the EIS spectra, the capacitive impedance is short-circuited, which in fact eliminates the $R_{\mathrm{ct}}$.

Consequently, only $R_{\mathrm{S}}$ remains at the high frequency intercept of the spectra. Meanwhile, the low frequency intercepts denote the sum of the values of $R_{S}$ and $R_{\mathrm{ct}}$. As a result, in the present case, it can be said that the diameters of the semicircles shown in Fig. 2 define the value of $R_{\mathrm{ct}}$ for the respective river water systems. From the close view of the EIS spectra (see inset of Fig. 2), order of resistivity of the river water was as follows:

\section{$R_{\mathrm{s}}($ Dawki $)>R_{\mathrm{s}}($ Surma $)>R_{\mathrm{s}}($ Buriganga $)$}

This observation suggests that Buriganga river water is highly conductive in comparison with other river waters. Correspondingly, this measurement ensures that the Buriganga river water contains huge TDS $(0.664-0.694 \mathrm{~g} / \mathrm{L}$, see Table 1), whereas Dawki and Surma river contains 0.043-0.12 g/L and 0.063-0.083 g/L TDS, respectively. In majority cases, high levels of TDS are originated due to the presence of chlorides of potassium and sodium. These ions have light or no short-term health risks, but toxic ions such as arsenic, nitrate, cadmium, etc., are also dissolved in the water which causes increase in TDS. The disposal of electrolytes from various industries installed over the banks of the river Buriganga and/or nitrate/nitrite ions generated due to biological conversion of nitrogenous pollutants perhaps made the Buriganga river to show high level TDS.

Conversely, the radius of the EIS spectra represents the charge transfer resistance, which varies with the concentration of the charge carrier species. From the fitted EIS curves, the charge transfer $\left(R_{\mathrm{ct}}\right)$ was found to be $132 \pm 4,217 \pm 3$ and $1120 \pm 8 \mathrm{k} \Omega$ for Surma, Dawki and Buriganga river waters, respectively, at $0 \mathrm{~V}$. Here, it is to note that the $\mathrm{pH}$ of the river water streams was found slightly basic $(8.0>\mathrm{pH}>7.0)$. In such a medium, a platinum electrode can reduce oxygen as per following reactions (Geniès et al. 1998; Strbac 2011) 
Scheme 1 A schematic representation of experimental setup
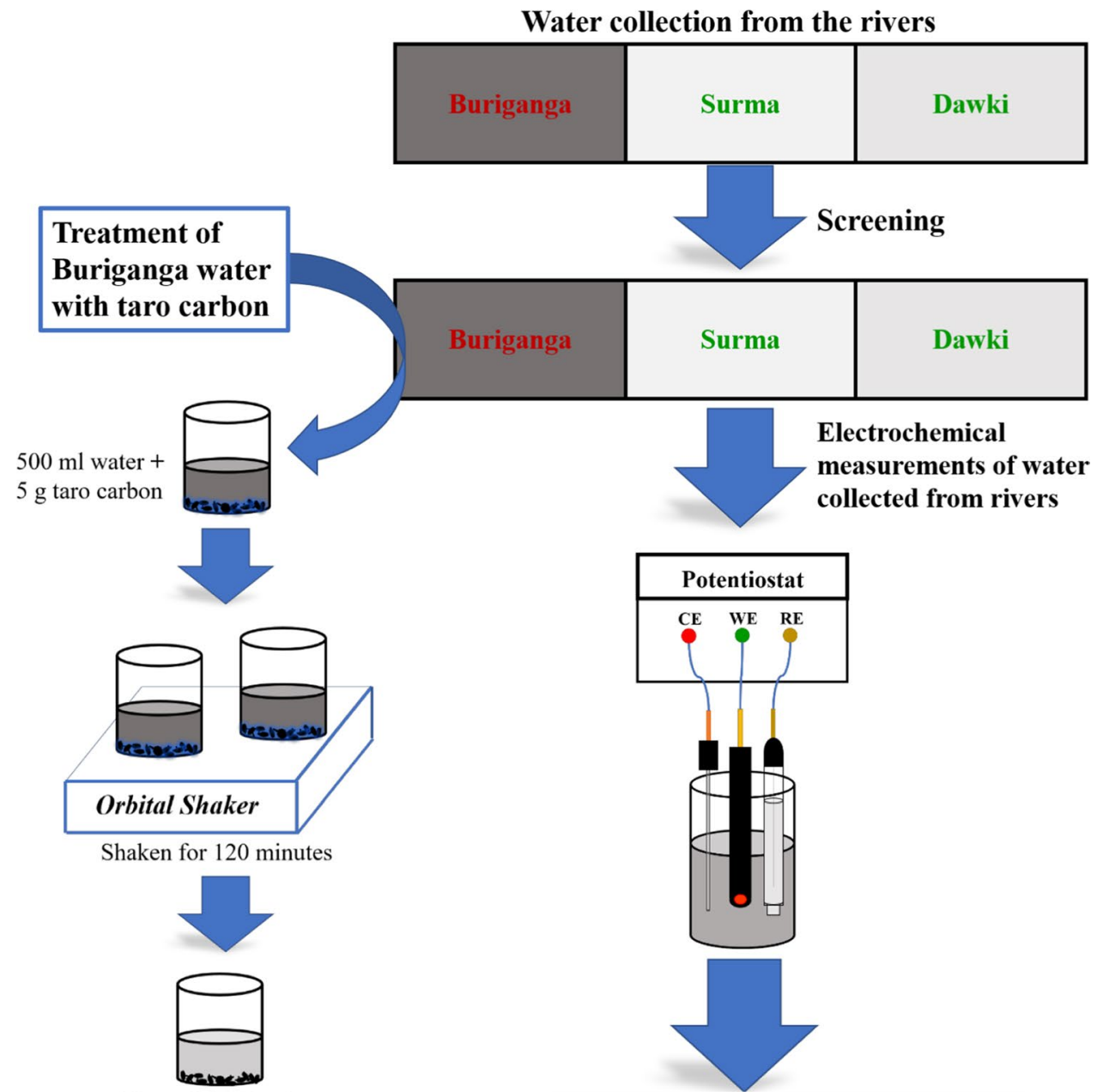

Allowed for 60 minutes
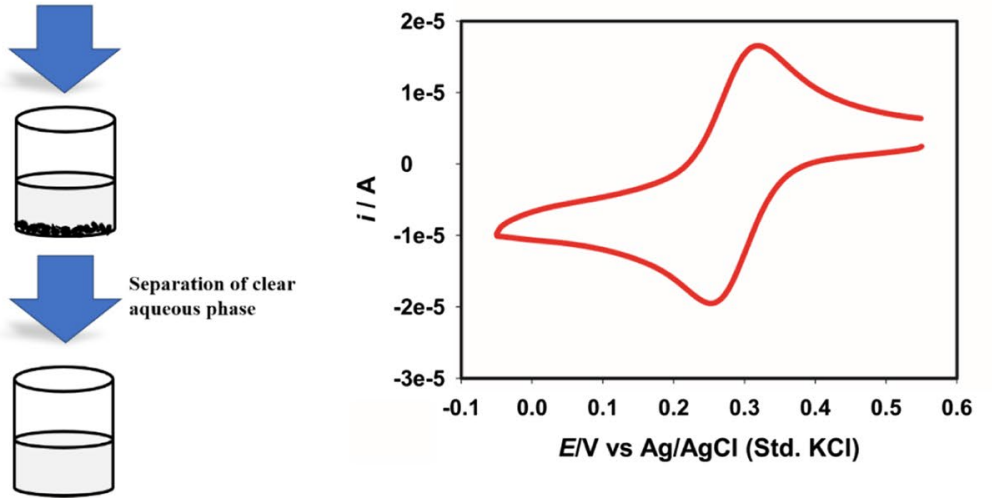

$\mathrm{O}_{2}+2 \mathrm{H}_{2} \mathrm{O}+4 \mathrm{e}^{-} \rightarrow 4 \mathrm{OH}^{-} \quad(4$ electron transfer $)$

$\mathrm{O}_{2}+\mathrm{H}_{2} \mathrm{O}+2 \mathrm{e}^{-} \rightarrow \mathrm{HO}_{2}^{-}+\mathrm{OH}^{-} \quad$ (2 electron transfer $)$

$$
\mathrm{H}_{2} \mathrm{O}+\mathrm{HO}_{2}^{-}+2 \mathrm{e}^{-} \rightarrow 3 \mathrm{OH}^{-}
$$

Under the experimental conditions and as per above reactions, the charge transfer should be quite difficult if the medium does not contain enough charge carrier like Pt electrode experienced highest charge transfer resistance implying that this river water contained least DO. From field analysis, the DO level of Dawki and Surma river was to be in the range of 5.6-6.8 $\mathrm{mg} / \mathrm{L}$ and $5.2-6.9 \mathrm{mg} / \mathrm{L}$, respectively, while the Buriganga river contained alarmingly low level of DO (1.47-4.4 mg/L, see Table 1).

According to a recent report, the DO level of river water systems even downs to zero in the dry seasons (Whitehead et al. 2018). Note that a typical air saturated fresh water 


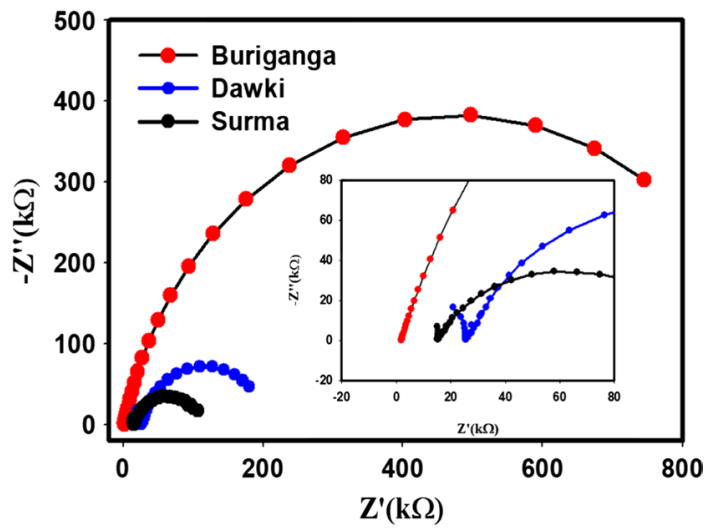

Fig. 2 EIS spectra of different river waters recorded using a Pt disk electrode at $0 \mathrm{~V}$ versus $\mathrm{Ag} / \mathrm{AgCl}$ (sat. $\mathrm{KCl}$ ). Inset shows enlarged view of solution resistance

contains DO of ca. $7.56 \mathrm{mg} / \mathrm{L}$ at $30{ }^{\circ} \mathrm{C}$ (Peterson and Risberg 2009). The lower DO is resulted in the marine systems for two main reasons: firstly, water with high concentrations of dissolved solids such as salt decreases DO level, and secondly, excessive growth of algae is promoted by phosphorus and/or nitrogen. While algae die and decompose, the process consumes dissolved oxygen (Peterson and Risberg 2009). Thus, the direct discharge of organic and or inorganic pollutants from point sources and nonpoint sources into the Buriganga river increased the concentration of dissolved solids and caused lowering of DO level.

\section{ORP and metallic corrosion}

Figure 3 shows the polarization curves of an iron electrode recorded using different river waters. Note that open circuit potential (OCP) of Buriganga, Dawki and Surma river waters lie at $-0.68 \mathrm{~V},-0.48 \mathrm{~V}$ and $-0.36 \mathrm{~V}$, respectively. The most negative OCP exhibited by the Buriganga river indicates that its water contains enough reductants, perhaps due to presence of organic wastes (which was confirmed by the estimation of large COD value 196-218 mg/L). Later the results were verified by means of in situ evaluation of ORP values as reported in Table 1. The Buriganga river water showed negative ORP values $(-292$ to $-300 \mathrm{mV})$ while the other river water showed positive values (ca. $+200 \mathrm{mV}$ ). The negative ORP values of Buriganga river water indicate that high level reluctant/antioxidants are present in the water system. However, the evaluation of corrosion rate of a metal such as iron may be an indicator of water quality of a certain system. The corrosion rate of a metal under test can be calculated from the slopes of $\log (i)$ versus $E$ plots as shown in Fig. 3.

The corrosion rate of a metal is often evaluated by measuring the equilibrium currents between opposing (anodic and cathodic) reactions. In the anode surface, metal particles are oxidized by releasing electrons into the metal strip. Meanwhile, in the cathode compartment, the species (often $\mathrm{O}_{2}$ or $\mathrm{H}^{+}$) in solution is reduced by receiving electrons from the metal. While the rates of these two opposing processes are balanced, then no virtual electrical current is observed. These two processes may take place on similar metals or on different two metals which are electrically connected. In conjunction with the principle, the corrosion process assumes that the rates of both processes (anodic and cathodic) are controlled by the kinetics of the electron-transfer reaction at the surface of the test metal. Note that an electrochemical process under kinetic control satisfy the Tafel Eq. (4) (Gileadi and Kirowa-Eisner 2005; Alam et al. 2018)

$\ln I=\ln I_{\mathrm{o}}+\ln \frac{\eta F \beta}{R T}$

Here, net current $(I)$ is related to corrosion current $\left(I_{\mathrm{o}}\right)$ and over potential $\left(\eta=E-E^{\mathrm{o}}\right)$. Using the above approximation, the value $I_{\mathrm{o}}$ was evaluated as $31.6 \pm 2.1 \mu \mathrm{mA}, 10.1 \pm 1.5 \mu \mathrm{A}$ and $9.5 \pm 1.1 \mu \mathrm{A}$ for Buriganga, Dawki and Surma river,

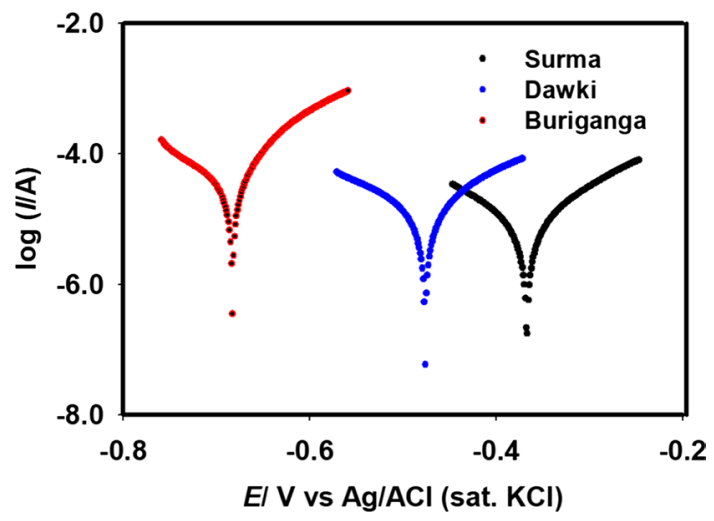

Fig. 3 The Tafel plots of Fe electrode recorded for different river waters under room condition

Table 1 In situ determined physical and chemical parameters of river waters

\begin{tabular}{lllllllll}
\hline Rivers & $\mathrm{T}\left({ }^{\circ} \mathrm{C}\right)$ & $\mathrm{pH}$ & $\mathrm{ORP}(\mathrm{mV})$ & $\mathrm{TDS}(\mathrm{g} / \mathrm{L})$ & $\mathrm{DO}(\mathrm{mg} / \mathrm{L})$ & $\mathrm{NO}_{3}{ }^{-}(\mathrm{mg} / \mathrm{L})$ & $\mathrm{NH}(\mathrm{mg} / \mathrm{L})$ & $\mathrm{COD}(\mathrm{mg} / \mathrm{L})$ \\
\hline Dawki & $28.1-28.5$ & $7.01-7.03$ & +203 to +209 & $0.043-0.12$ & $5.6-6.8$ & $<0.1$ & $<0.1$ & - \\
Surma & $28.0-28.3$ & $6.93-7.01$ & +184 to +205 & $0.063-0.083$ & $5.2-6.9$ & $<0.1$ & $<0.1$ & - \\
Buriganga & $28.8-29.04$ & $6.50-7.50$ & -292 to -310 & $0.664-0.694$ & $1.47-4.40$ & $107-157$ & $270-420$ & $197-218$ \\
\hline
\end{tabular}


respectively. Since current intensity corresponds to the rate of an electrochemical process, thus it can be assumed that the Buriganga river water could corrode iron three times faster than Surma or Dawki river water. The corrosion current is highly related to water quality such as salinity (Melchers 2015). High level dissolved solids, such as chlorides, nitrates and sulfates can induce chemical or bio-chemical corrosion of metal. The above observation, thus, ensures that Buriganga water contains excessive dissolved solids.

\section{Evaluation of ammonia and nitrate}

In the previous section, it has been reported that Buriganga river water has TDS above the acceptable level. According to geographical position of river Buriganga, saline water intrusion from the nearest Bay of Bengal is not possible. However, increased nitrate concentration may contribute to the TDS of the water stream. In the marine waters nitrate ions often coexists with ammonia as they are inter convertible (Jensen et al. 1985).

Ammonia may enter into the water stream via municipal effluents and/or the biological disintegration of nitrogenous wastes from animals (Chen et al. 2016). Several secondary means such as runoff from crop lands, air deposition, nitrogen fixation, etc., can also introduce ammonia to the natural water systems. Ammonia exists in water having an equilibrium between molecular $\left(\mathrm{NH}_{3}\right)$ and its ionized form $\left(\mathrm{NH}_{4}{ }^{+}\right)$. Toxicity to marine lives arises mainly from molecular $\mathrm{NH}_{3}$, with minor contribution from $\mathrm{NH}_{4}{ }^{+}$(Miller et al. 1990). Due to low DO and high level of COD values, we assumed that Buriganga river stream must contain considerable ammonia concentration. We, therefore, evaluated in situ ammonia from the river waters using spectrometric method. The data are reported in Table 1. Note that concentration of ammonia was $270-420 \mathrm{mg} / \mathrm{L}$ in the case of Buriganga river water, while it was bellow detection level for Surma and Dawki river waters. In the biologically contaminated waste water systems under aerobic condition, nitrifying bacteria consumes oxygen by converting ammonia into nitrite $\left(\mathrm{NO}_{2}{ }^{-}\right)$, consecutively Nitrobacter transforms nitrite into nitrate ions $\left(\mathrm{NO}_{3}{ }^{-}\right)$as per following reaction mechanism (Schmidt et al. 2002).

$2 \mathrm{NH}_{3}+3 \mathrm{O}_{2} \rightarrow 2 \mathrm{NO}_{2}^{-}+2 \mathrm{H}^{+}+2 \mathrm{H}_{2} \mathrm{O}$

$2 \mathrm{NO}_{2}^{-}+\mathrm{O}_{2} \rightarrow 2 \mathrm{NO}_{3}^{-}$

Nitrate ions in groundwater also may be introduced from the point sources such as sewage disposal systems and livestock facilities, inadvertent application of fertilizer in the cropland, parks, gardens, etc. As the Buriganga river water contains significant concentration of ammonia originated from biological waste, the environment is ideal for bacterial conversion of ammonia into nitrite/nitrate ions. Thus, we took attempts to detect the presence of nitrate ions in river waters using a Pt-Cu disk as working electrode.

Figure $4 \mathrm{~A}$ shows the $\mathrm{CVs}$ of river waters recorded at a scan rate of $50 \mathrm{mV} / \mathrm{s}$ using a Pt-Cu working electrode within the potential window between 0 and $-1.4 \mathrm{~V}$. At the surface of a $\mathrm{Pt}-\mathrm{Cu}$ electrode, nitrate ions are converted into ammonia ions under reduction condition as per following reactions (Hasnat et al. 2014).

$\mathrm{NO}_{3}^{-}+\mathrm{H}_{2} \mathrm{O}+2 \mathrm{e}^{-} \rightarrow \mathrm{NO}_{2}^{-}+2 \mathrm{OH}^{-}$

$\mathrm{NO}_{2}^{-}+5 \mathrm{H}_{2} \mathrm{O}+6 \mathrm{e}^{-} \rightarrow \mathrm{NH}_{3}+7 \mathrm{OH}^{-}$

Thus, a broad reduction wave could be obtained (shown in Fig. 4B) if nitrate/nitrite ions are present in the water sample. Note that the CVs obtained for Surma and Dawki Rivers do not show any reduction wave while the Buriganga water shows sharp reduction peak between $-0.83 \mathrm{~V}$ and $-1.2 \mathrm{~V}$ whose profile almost superimposes that obtained for $150 \pm 3 \mathrm{ppm} \mathrm{NaNO}_{3}$ in $0.1 \mathrm{M} \mathrm{KCl}$ solution prepared by deionized water. Consequently, it is experimentally evident that Buriganga river water contains $\mathrm{N}$-nitrate/nitrite. However, the field data measured with ion-selective membrane electrode showed that Buriganga river water contained 107-157 mg/L nitrate/nitrite ions, which ensures acute anthropogenic contamination in the river Buriganga. Consequently, it can be said that the River Buriganga one of the World's most endangered rivers which is facing increased TDS, acute ammonia concentration and lowered DO.

\section{Sediment analysis}

As the water flow of Buriganga river contains huge inorganic and organic contaminants, thus there is a high potentiality of deposition of insoluble contaminants on the bottom of the river. In order to determine the contaminants in the sediments, steps were taken in terms of X-ray analysis. Scanning electron microscopic (SEM) image can explain the surface morphology of a material, while coupled EDS can detect even trace quantities of elements within a material. Hence, in order to examine the texture and composition, the collected sediment specimens were dried first at $110^{\circ} \mathrm{C}$ to remove all of water constituents and then meshed properly.

Next, FE-SEM images were taken along with recording of EDS spectra. It can be seen from Fig. 5 that the mineral composition of the soils of all of the river soils is almost similar and comprise mainly $\mathrm{Ca}, \mathrm{Si}, \mathrm{K}, \mathrm{Fe}, \mathrm{Mg}$ and $\mathrm{Al}$ with traces of $\mathrm{Zn}$ and $\mathrm{S}$. The presence of oxygen indicates that these elements exist in the form of oxides. The SEM images of Dawki (panel A of Fig. 5) and Surma (panel B of Fig. 5) indicate that their sediments are comprised of coarse particles with 


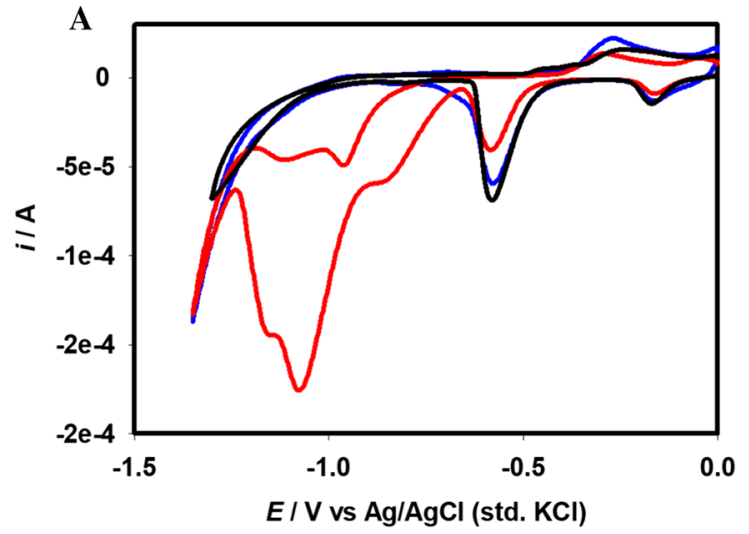

Fig. 4 Cyclic voltammograms of river waters recorded at a scan rate of $50 \mathrm{mV} / \mathrm{s}$ using a Pt-Cu working electrode in $0.1 \mathrm{M} \mathrm{KCl}$. A Black line: Surma river water, Blue line: Dawki river water, Red line: Bur-

sharp edges. Meanwhile, the texture of Buriganga (panel $\mathrm{C}$ of Fig. 5) soil particles are rather smooth with irregular shapes. Such different texture of specimen indicates that insoluble organic particles originated from the disintegration of municipal and industrial wastages have been deposited at the bottom and bank of the Buriganga River.

\section{Restoration of water quality}

Carbon materials derived from various sources have excellent efficiency to remove different pollutants from water (Gaikwad and Balomajumder 2017; Rashidi and Yusup 2017; Tchikuala et al. 2017; Ratan et al. 2018; Menya et al. 2018; Chen et al. 2018). Thus, batch experiments were performed to restore water parameters of Buriganga river water using carbonous materials synthesized from taro stems (in this article synthesized carbon is designated as taro carbon). Figure 6 shows the image of taro stems and corresponding SEM image of taro carbon.

Here, to perform the batch experiment, at first water samples were collected in a tank from the river and removed all suspended particles. Next, water tank was allowed to stay under open air for $48 \mathrm{~h}$, where the temperature varied between $24{ }^{\circ} \mathrm{C}$ and $36{ }^{\circ} \mathrm{C}$. From the water tank, $500 \mathrm{~mL}$ was then taken in a batch reactor along with $5 \mathrm{~g}$ taro carbon.

At this stage, the batch reactor was shaken using an orbital shaker for $120 \mathrm{~min}$ (see Scheme 1). After completion of shaking, the batch was allowed to rest for another $60 \mathrm{~min}$. Then, the clear aqueous phase was separated for chemical analysis.

Figure 7 shows analytical results, which compares some water parameters before and after treatment with taro carbon. It is seen from this figure that after treatment, COD decreased by ca. $90 \pm 2 \%$, ammonia concentration decreased by $85 \pm 3 \%$, nitrate concentration decreased by $52 \pm 2 \%$, and

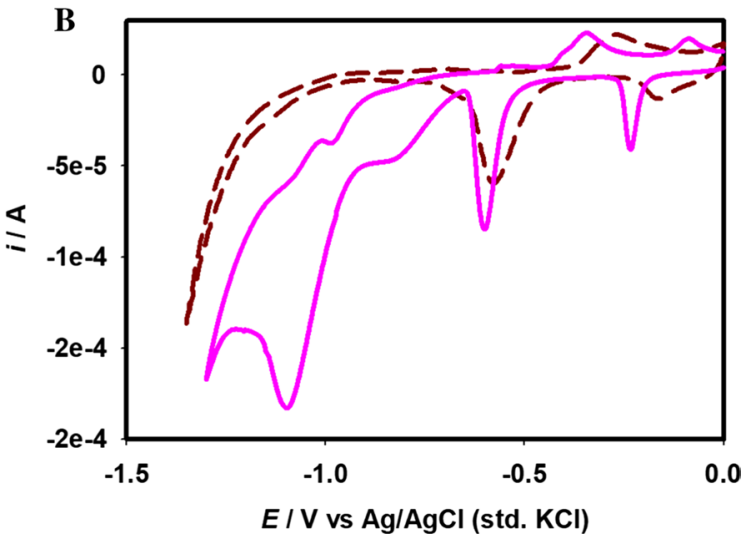

iganga river water; $\mathbf{B}$ Responses of $\mathrm{Pt}-\mathrm{Cu}$ electrode toward nitrate reduction reactions under ideal condition; Dotted line: $0.1 \mathrm{M} \mathrm{KCl}$, Pink line: $150 \mathrm{ppm} \mathrm{NaNO}_{3}$

TDS decreased by $63 \pm 3 \%$. Additionally, after the treatment, ORP value of the water treated water sample was found change to $+160 \mathrm{mV}$ from $-310 \mathrm{mV}$ and $\mathrm{DO}$ level raised to $5.1 \mathrm{mg} / \mathrm{L}$ from $2.3 \mathrm{mg} / \mathrm{L}$. This observation suggests that taro carbon is an efficient adsorbent to remove undesired dissolved particles from the wastewater system. It is worthwhile, to note that because of high absorbability carbonoues materials can remove organic materials very easily from water (Hami et al. 2007).

As a result, COD value decreased significantly in the present case. However, a drastic removal of ammonia using a carbonous materials is difficult (Park and Jin 2005). In the present case, removal of ammonia not only occurred by absorbability of taro carbon but also ammonia generation was inhibited as the suspended particles and TOC were removed, which perhaps indirectly contributed to decrease ammonia level in the wastewater at $\mathrm{pH} \sim 7.0$.

Consequently, electrochemical analysis reveals that river Buriganga is extremely polluted river in Bangladesh due to industrial and human waste disposal, and the contamination can be minimized by treating with activated carbon synthesized from taro stems.

\section{Conclusion}

In this research, laboratory-based electrochemical experiments in terms of EIS, CV and OCP were performed to detect and quantify pollutants in Buriganga river water and then compared with two other sources of fresh water from Surma and Dawki river to perceive the pollution level of Buriganga river. In EIS study, low water resistance $\left(R_{\mathrm{S}}\right)$ of Buriganga river compared with Surma and Dawki rivers revealed the presence of highly conducting materials which stands for high TDS value. Additionally, the higher value 


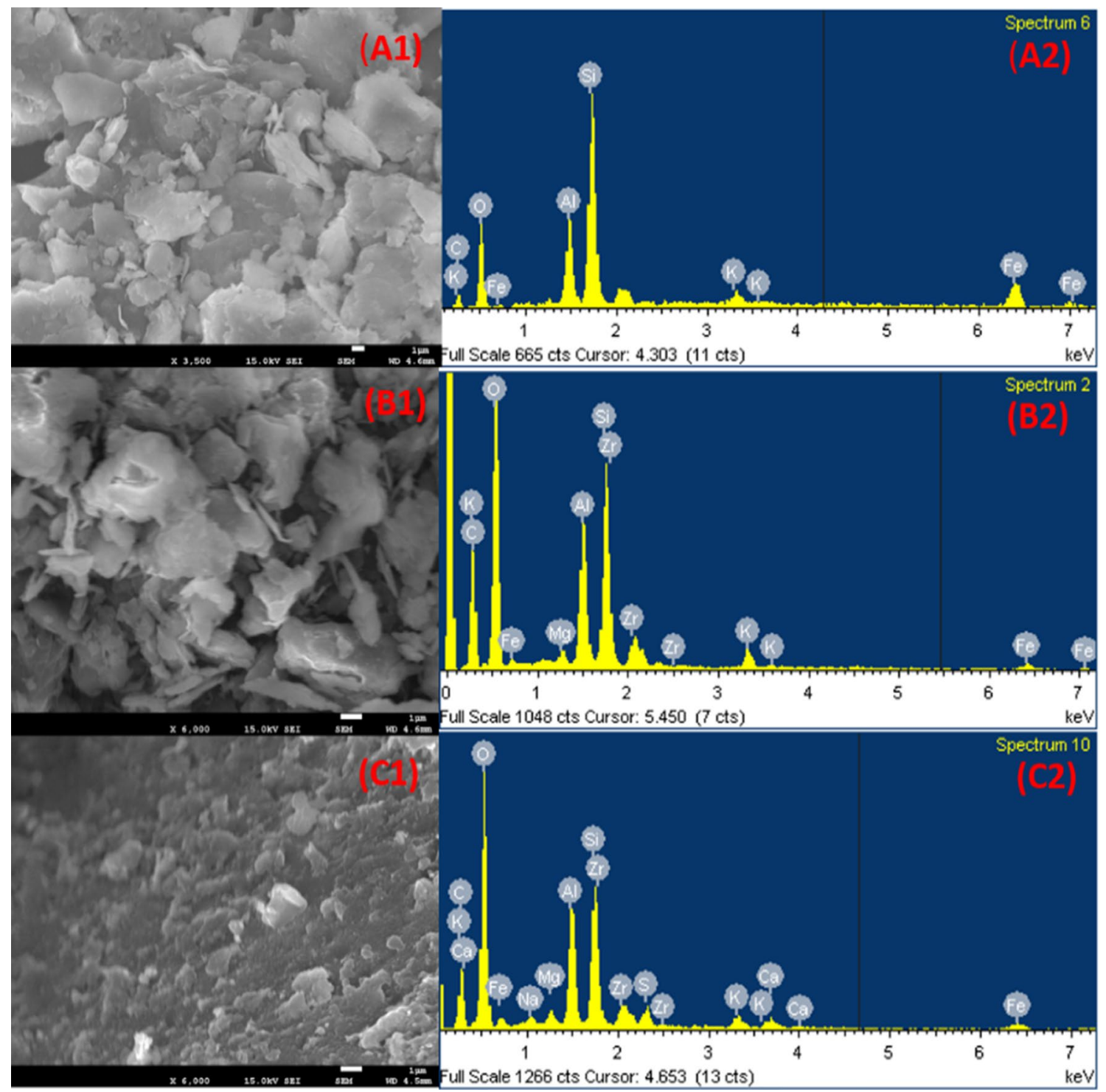

Fig. 5 FE-SEM images and associated EDS spectra of soil specimen collected from different rivers. A Dawki, B Surma and C Burigana soil

Fig. 6 Image of taro stem (A) and SEM image of taro carbon (B)
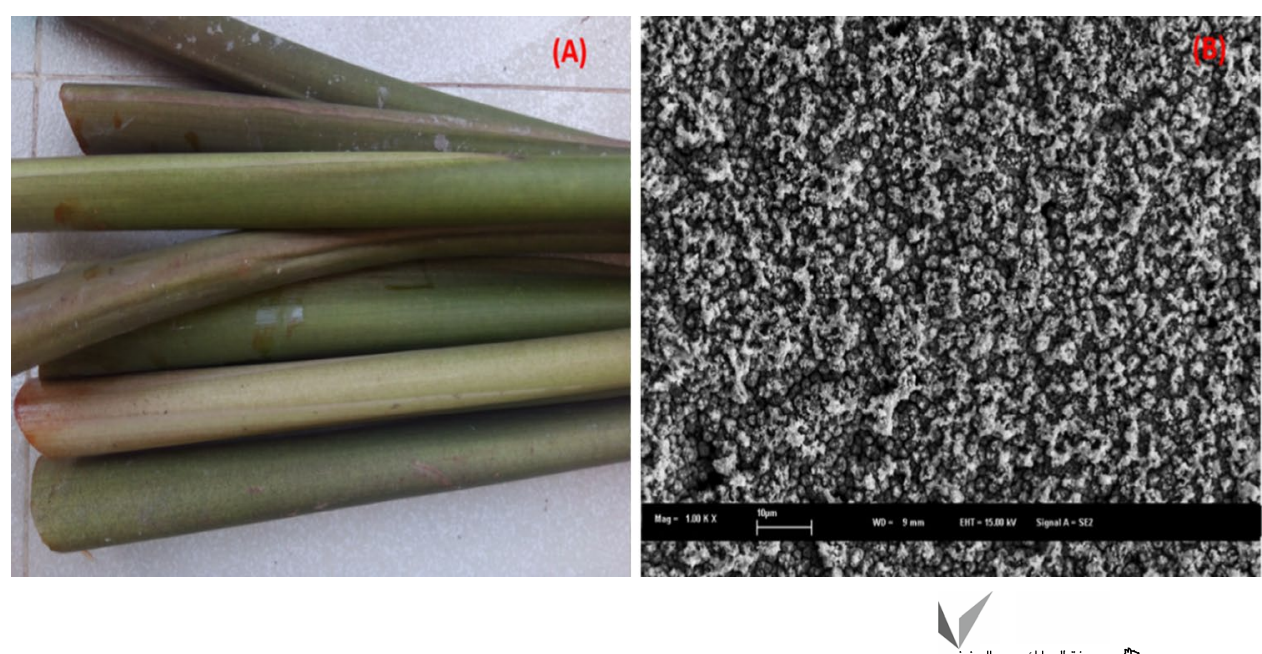

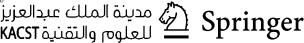




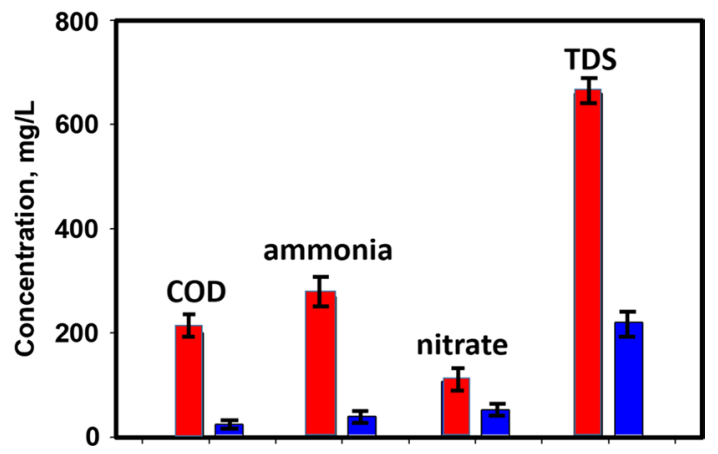

Fig. 7 Batch treatment of Buriganga river water with standard errors on average. Volume: $500 \mathrm{~mL}$, adsorbent (taro carbon) dosage: $5 \mathrm{~g}$ [red mark: untreated water; blue mark: treated water]

of charge transfer resistance $\left(R_{\mathrm{ct}}\right)$ of Pt electrode showed the lack of charge carriers like dissolved oxygen in Buriganga river water. Most surface water has a positive ORP values $(+200$ to $+600 \mathrm{mV})$ which was observed in the case of Surma and Dawki river waters. Water with negative ORP values has a higher amount of reducing agents as it was found in the case of Buriganga river water $(-292$ to $-300 \mathrm{mV})$. The Buriganga river water corrodes iron three times rapidly than Surma or Dawki river water. A COD analysis can easily measure the number of organics contaminants in water. Due to dumping of huge municipal wastage, the Buriganga river water exhibited high COD $(197-218 \mathrm{mg} / \mathrm{L})$. Ammonia is toxic to fish while its concentration reaches $>0.03 \mathrm{mg} / \mathrm{L}$. WHO recommends maximum ammonia level as $0.2 \mathrm{mg} / \mathrm{L}$ and $50 \mathrm{mg} / \mathrm{L}$ nitrate in drinking water. However, Buriganga water contains alarmingly high level of ammonia (270-420 mg/L) and nitrate ions $(107-157 \mathrm{mg} / \mathrm{L})$. The DO level in Buriganga was found in the range $1.47-4.40 \mathrm{mg} / \mathrm{L}$. Fishes and crustaceans receive oxygen for respiration through their gills, while plant lives and phytoplankton need dissolved oxygen for respiration. If DO level in water drops below $5.0 \mathrm{mg} / \mathrm{L}$, aquatic lives are put under stress. These indicators are enough to conclude the death of fishes and other aquatic creatures in the river Buriganga. Lastly, the presence of insoluble organic particles originated from the disintegration municipal and industrial wastages was confirmed by the sediment analysis of Buriganga River. In conclusion, it can be said that the water of the Buriganga is now acutely polluted and cumulative municipal filth and human waste have turned it like a stream of black gel. Sustainable actions are highly recommended to revert the water parameters to the acceptable standards. However, treatment using taro carbon may be a cost-effective means to treat wastewater like Buriganga river water, and it was found that COD value and ammonia concentration decreased drastically and the TDS value, nitrate concentration also decreased.
Acknowledgements The authors are indebted to TWAS and SIDA for a Research Grant (19-222 RG/CHE/AS_G). Ministry of Science and Technology, Bangladesh is acknowledged for the grant allocated for the year 2019-2020 (Project No. ES369). The Shahjalal University of Science and Technology research center is also acknowledged for allocating a partial grant (2018-2019). The authors thank Prof. M.M. Rahman (KAU, KSA) for helping sedimental analysis.

\section{Compliance with ethical standards}

Conflict of interest We do not have any conflict of interest.

Open Access This article is licensed under a Creative Commons Attribution 4.0 International License, which permits use, sharing, adaptation, distribution and reproduction in any medium or format, as long as you give appropriate credit to the original author(s) and the source, provide a link to the Creative Commons licence, and indicate if changes were made. The images or other third party material in this article are included in the article's Creative Commons licence, unless indicated otherwise in a credit line to the material. If material is not included in the article's Creative Commons licence and your intended use is not permitted by statutory regulation or exceeds the permitted use, you will need to obtain permission directly from the copyright holder. To view a copy of this licence, visit http://creativecommons.org/licenses/by/4.0/.

\section{References}

Alam MM, Hasnat MA, Rashed MA et al (2015) Nitrate detection activity of $\mathrm{Cu}$ particles deposited on pencil graphite by fast scan cyclic voltammetry. J Anal Chem 70:60-66. https://doi. org/10.1134/S1061934815010037

Alam MM, Rashed MA, Rahman MM et al (2018) Electrochemical oxidation of As(III) on Pd immobilized Pt surface: kinetics and sensing performance. RSC Adv 8:8071-8079. https://doi. org/10.1039/c7ra12576c

Chen H, Wang W, Xue L et al (2016) Effects of ammonia on anaerobic digestion of food waste: process performance and microbial community. Energy Fuels 30:5749-5757. https://doi. org/10.1021/acs.energyfuels.6b00715

Chen PA, Cheng HC, Wang HP (2018) Activated carbon recycled from bitter-tea and palm shell wastes for capacitive desalination of salt water. J Clean Prod 174:927-932. https://doi. org/10.1016/j.jclepro.2017.11.034

Deng W, Li Y (2018) Electrochemical sensor for determining the manganese content in molten iron. Electrochim Acta 265:265-274. https://doi.org/10.1016/j.electacta.2018.01.189

Dwivedi S, Mishra S, Tripathi RD (2018) Ganga water pollution: a potential health threat to inhabitants of Ganga basin. Environ Int 117:327-338

Falkenberg T, Saxena D, Kistemann T (2018) Impact of wastewaterirrigation on in-household water contamination. A cohort study among urban farmers in Ahmedabad, India. Sci Total Environ 639:988-996. https://doi.org/10.1016/j.scitotenv.2018.05.117

Farzbod A, Moon H (2018) Integration of reconfigurable potentiometric electrochemical sensors into a digital microfluidic platform. Biosens Bioelectron 106:37-42. https://doi.org/10.1016/j. bios.2018.01.048

Gaikwad MS, Balomajumder C (2017) Tea waste biomass activated carbon electrode for simultaneous removal of $\mathrm{Cr}(\mathrm{VI})$ and fluoride by capacitive deionization. Chemosphere 184:1141-1149. https:// doi.org/10.1016/j.chemosphere.2017.06.074 
Geniès L, Faure R, Durand R (1998) Electrochemical reduction of oxygen on platinum nanoparticles in alkaline media. Electrochim Acta 44:1317-1327. https://doi.org/10.1016/S0013-4686(98)00254-0

Gileadi E, Kirowa-Eisner E (2005) Some observations concerning the Tafel equation and its relevance to charge transfer in corrosion. Corros Sci 47:3068-3085. https://doi.org/10.1016/j.corsc i. 2005.05 .044

Hami ML, Al-Hashimi MA, Al-Doori MM (2007) Effect of activated carbon on BOD and COD removal in a dissolved air flotation unit treating refinery wastewater. Desalination 216:116-122. https:// doi.org/10.1016/j.desal.2007.01.003

Hasnat MA, Ben Aoun S, Nizam Uddin SM et al (2014) Copperimmobilized platinum electrocatalyst for the effective reduction of nitrate in a low conductive medium: mechanism, adsorption thermodynamics and stability. Appl Catal A 478:259-266. https ://doi.org/10.1016/j.apcata.2014.04.017

Jegdić B, Dražić DM, Popić JP (2008) Open circuit potentials of metallic chromium and austenitic 304 stainless steel in aqueous sulphuric acid solution and the influence of chloride ions on them. Corros Sci 50:1235-1244. https://doi.org/10.1016/j.corsc i.2008.01.012

Jensen A, Henriksen K, Rasmussen MB (1985) The distribution and interconversion of ammonium and nitrate in the Skallingen salt marsh (Denmark) and their exchange with the adjacent coastal water. In: Beeftink WG (ed) Ecology of coastal vegetation. Springer, Dordrecht, pp 357-366

Kabir MH, Sato M, Habbiba U, Yousuf TB (2018) Assessment of urban disaster resilience in Dhaka North City Corporation (DNCC), Bangladesh. Procedia Eng 212:1107-1114

Kamal MM, Malmgren-Hansen A, Badruzzaman ABM (1999) Assessment of pollution of the River Buriganga, Bangladesh, using a water quality model. Water Sci Technol 40:129-136

Khan AA, Khan A (2010) Ion-exchange studies on poly-o-anisidine $\mathrm{Sn}(\mathrm{IV})$ phosphate nano composite and its application as $\mathrm{Cd}(\mathrm{II})$ ion-selective membrane electrode. Cent Eur J Chem 8:396-408. https://doi.org/10.2478/s11532-010-0002-6

Khan A, Asiri AM, Khan AAP et al (2013) Sol-gel synthesis and characterization of conducting polythiophene/tin phosphate nano tetrapod composite cation-exchanger and its application as $\mathrm{Hg}$ (II) selective membrane electrode. J Sol-Gel Sci Technol 65:160-169. https://doi.org/10.1007/s10971-012-2920-6

Khan A, Khan AAP, Rahman MM, Asiri AM (2016) High performance polyaniline/vanadyl phosphate $\left(\mathrm{PANI}-\mathrm{VOPO}_{4}\right)$ nano composite sheets prepared by exfoliation/intercalation method for sensing applications. Eur Polym J 75:388-398. https://doi.org/10.1016/j. eurpolymj.2016.01.003

Kubicz J, Pawełczyk A, Lochyński P (2018) Environmental health risk posed by contamination of the individual water wells. Chemosphere 208:247-256. https://doi.org/10.1016/j.chemospher e.2018.05.182

Maria Rahman M, Akter N, Karim MR et al (2014) Optimization, kinetic and thermodynamic studies for removal of Brilliant Red (X-3B) using Tannin gel. J Environ Chem Eng 2:76-83. https:// doi.org/10.1016/j.jece.2013.11.023

McCafferty E (2005) Validation of corrosion rates measured by the Tafel extrapolation method. Corros Sci 47:3202-3215. https:// doi.org/10.1016/j.corsci.2005.05.046

Melchers R (2015) Effect of Water nutrient pollution on long-term corrosion of 90:10 copper nickel alloy. Materials 8:8047-8058. https://doi.org/10.3390/ma8125443

Menya E, Olupot PW, Storz H et al (2018) Production and performance of activated carbon from rice husks for removal of natural organic matter from water: a review. Chem Eng Res Des 129:271-296. https://doi.org/10.1016/j.cherd.2017.11.008

Miller DC, Poucher S, Cardin JA, Hansen D (1990) The acute and chronic toxicity of ammonia to marine fish and a mysid. Arch
Environ Contam Toxicol 19:40-48. https://doi.org/10.1007/ BF01059811

Mirqasemi MS, Homayoonfal M, Rezakazemi M (2020) Zeolitic imidazolate framework membranes for gas and water purification. Environ Chem Lett 18:1-52

Moya A, Gabriel G, Villa R, Javier del Campo F (2017) Inkjetprinted electrochemical sensors. Curr Opin Electrochem 3:29-39

Park SJ, Jin SY (2005) Effect of ozone treatment on ammonia removal of activated carbons. J Colloid Interface Sci 286:417-419. https ://doi.org/10.1016/j.jcis.2005.01.043

Peterson F, Risberg J (2009) Low Dissolved Oxygen in Water - Causes. Minnesota pollution control agency 11:2. https://www.pca.state .mn.us/sites/default/files/wq-iw3-24.pdf

Rahman MM, Khan A, Asiri AM (2015) Chemical sensor development based on poly ( $o$-anisidine)silverized-MWCNT nanocomposites deposited on glassy carbon electrodes for environmental remediation. RSC Adv 5:71370-71378. https://doi.org/10.1039/c5ra1 0793h

Rashidi NA, Yusup S (2017) A review on recent technological advancement in the activated carbon production from oil palm wastes. Chem Eng J 314:277-290. https://doi.org/10.1016/j. cej.2016.11.059

Ratan JK, Kaur M, Adiraju B (2018) Synthesis of activated carbon from agricultural waste using a simple method: characterization, parametric and isotherms study. Mater Today Proc 5:3334-3345

Rezakazemi M, Khajeh A, Mesbah M (2018) Membrane filtration of wastewater from gas and oil production. Environ Chem Lett $16: 367-388$

Sander A, Berghult B, Elfström Broo A et al (1996) Iron corrosion in drinking water distribution systems - the effect of $\mathrm{pH}$, calcium and hydrogen carbonate. Corros Sci 38:443-455. https://doi. org/10.1016/0010-938X(96)00142-4

Schmidt I, Sliekers O, Schmid M et al (2002) Aerobic and anaerobic ammonia oxidizing bacteria-competitors or natural partners? FEMS Microbiol Ecol 39:175-181. https://doi. org/10.1111/j.1574-6941.2002.tb00920.x

Sheikh M, Pazirofteh M, Dehghani M et al (2019) Application of ZnO nanostructures in ceramic and polymeric membranes for water and wastewater technologies: a review. Chem Eng J. https://doi. org/10.1016/j.cej.2019.123475

Soja R, Starkel L (2007) Extreme rainfalls in Eastern Himalaya and southern slope of Meghalaya Plateau and their geomorphologic impacts. Geomorphology 84:170-180. https://doi.org/10.1016/j. geomorph.2006.01.040

Strbac S (2011) The effect of $\mathrm{pH}$ on oxygen and hydrogen peroxide reduction on polycrystalline Pt electrode. Electrochim Acta 56:1597-1604. https://doi.org/10.1016/j.electacta.2010.10.057

Su S, Chen S, Fan C (2018) Recent advances in two-dimensional nanomaterials-based electrochemical sensors for environmental analysis. Green Energy Environ 3:97-106

Tanjila N, Rayhan A, Alam MS et al (2016) Electrochemical and spectroscopic insights of interactions between alizarin red $\mathrm{S}$ and arsenite ions. RSC Adv 6:93162-93168. https://doi.org/10.1039/ c6ra21356a

Tavangar T, Karimi M, Rezakazemi M et al (2020) Textile waste, dyes/ inorganic salts separation of cerium oxide-loaded loose nanofiltration polyethersulfone membranes. Chem Eng J 385:123787. https ://doi.org/10.1016/j.cej.2019.123787

Tchikuala E, Mourão P, Nabais J (2017) Valorisation of natural fibres from african baobab wastes by the production of activated carbons for adsorption of diuron. Procedia Eng 200:399-407. https://doi. org/10.1016/j.proeng.2017.07.056

Wang Q, Yang Z (2016) Industrial water pollution, water environment treatment, and health risks in China. Environ Pollut 218:358-365. https://doi.org/10.1016/j.envpol.2016.07.011

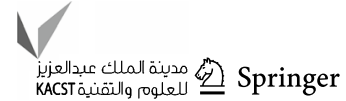


Whitehead P, Bussi G, Hossain MA et al (2018) Restoring water quality in the polluted Turag-Tongi-Balu river system, Dhaka: modelling nutrient and total coliform intervention strategies. Sci Total Environ 631-632:223-232. https://doi.org/10.1016/j.scito tenv.2018.03.038

WHO (2003) Ammonia in Drinking-water background document for development of WHO guidelines for drinking-water quality. https ://www.who.int/water_sanitation_health/water-quality/guidelines /chemicals/ammonia.pdf?ua=1. Accessed 3 Dec 2019

WHO (2017) https://www.who.int/news-room/detail/12-07-2017-2-1billion-people-lack-safe-drinking-water-at-home-more-than-twice -as-many-lack-safe-sanitation. Accessed 3 Dec 2019
Wick K, Heumesser C, Schmid E (2012) Groundwater nitrate contamination: factors and indicators. J Environ Manag 111:178-186. https://doi.org/10.1016/j.jenvman.2012.06.030

World Map/World Atlas/Atlas of the World Including Geography Facts and Flags-Worldatlas.com-WorldAtlas.com. https://www. worldatlas.com/. Accessed 3 Dec 2019

Publisher's Note Springer Nature remains neutral with regard to jurisdictional claims in published maps and institutional affiliations. 